\title{
Adaptation to climate change in urban areas: Climate-greening London, Rotterdam, and Toronto
}

\author{
Heleen-Lydeke P. Mees and Peter P. J. Driessen*
}

\begin{abstract}
This article aims to gain insight into the governance capacity of cities to adapt to climate change through urban green planning, which we will refer to as climate-greening. The use of green space is considered a no-regrets adaptation strategy, since it not only absorbs rainfall and moderates temperature, but simultaneously can contribute to the sustainable development of urban areas. However, green space competes with other socio-economic interests that also require space. Urban planning can mediate among competing demands for land use, and, as such, is potentially useful for the governance of adaptation. Through an in-depth case study of three frontrunners in adaptation planning (London, Rotterdam, and Toronto), the governance capacity for climate-greening urban areas is analysed and compared. The framework we have developed utilizes five sub-capacities: legal, managerial, political, resource, and learning. The overall conclusion from the case studies is that the legal and political subcapacities are the strongest. The resource and learning sub-capacities are relatively weak, but offer considerable growth potential. The managerial sub-capacity is constrained by compartmentalization and institutional fragmentation, two key barriers to governance capacity. These are effectively blocking the mainstreaming of adaptation in urban planning. The biggest opportunities to enhance governance capacity lie in the integration of adaptation considerations into urban-planning processes, the establishment of links between adaptation and mitigation policies, investment in training programmes for staff and stakeholders in adaptation planning, and providing infrastructure for learning processes.
\end{abstract}

\section{INTRODUCTION}

Cities are vulnerable to the impacts of climate change. First, they are vulnerable to flood risk resulting from an increase in frequency and intensity of precipitation because of the relatively high impermeability of urban surfaces. Second, urban areas can be exposed to warmer temperatures

\footnotetext{
* The authors would like to thank the journal's anonymous referees for their valuable comments, the respondents for their valuable input, and Clare Barnes for the English-language check. The authors may be contacted at Environmental Governance, Copernicus Institute of Sustainable Development, Utrecht University, P.O. Box 80.115, 3508 TC Utrecht, The Netherlands, <h.mees@geo.uu.nl> and <p.driessen@geo.uu.nl>.
} 
of up to four degrees Celsius compared with rural areas due to the so-called Urban Heat Island (UHI) effect resulting from the urbanization process, which replaces natural surfaces with built ones. ${ }^{1}$ Increases in average temperature will enhance the UHI effect. Third, urban environments are less healthy than rural areas, and again climate change will worsen this situation as a result of stress from heat waves and flood events, and increased occurrence of vector-borne diseases. ${ }^{2}$ In sum, climate change is expected to exacerbate already overburdened urban environments, and hence the linkages between climate impacts and socio-economic drivers form an impressive challenge for urban planning. ${ }^{3}$

Although the majority of climate policy developed by urban planners is focused on mitigation, an appreciation of the need for adaptation policy has recently emerged, in particular in Europe where a new area of public policy is emerging. ${ }^{4}$ There are various means to address key urban adaptation issues such as urban flooding and heat stress. So far, more traditional adaptation responses have dominated, such as increasing the capacity of sewage systems or drainage canals for stormwater management, and installing air-conditioning for heat-stress management. However, urban planners are gradually becoming more aware of the potential of green infrastructural measures $^{5}$ to regulate water quantities and moderate temperature. Several studies have shown that green space at various scales can reduce rainwater run-off and moderate temperature by using nature's capacity to absorb or control the impacts of climate change. ${ }^{6}$ A study in the Manchester conurbation has shown that urban green space has significant potential to moderate temperature and decrease surface run-off of rainwater. For instance, its modelling work suggests that increasing the green space cover by ten per cent in high-density residential areas could keep surface temperatures at or below the baseline 1961-1990 level for most of the century. Conversely, by removing ten per cent of green cover from these areas, maximum surface temperatures increase by 7 to 8.2 degrees Celsius by the 2080s, assuming the highest emissions scenario. ${ }^{7}$ Moreover, the use of green infrastructure may help to mitigate climate change by reducing greenhouse gas emissions and energy demand for the cooling of buildings. In addition to providing climate

\footnotetext{
${ }^{1}$ Rahola et al., Heat in the city. An inventory of knowledge and knowledge deficiencies regarding heat stress in Dutch cities and options for its mitigation, Knowledge for Climate, reportnumber KvR 013/2009 (2009). See also $<$ www.urbanheatislands.com>.

${ }^{2}$ Colin D. Butler and David O. Harley, Primary, secondary, and tertiary effects of eco-climatic change: The medical response, 86(1014) Postgraduate Medical Journal 230 (2010).

${ }^{3}$ Sarah J. Lindley et al., The Role of Spatial Risk Assessment in the Context of Planning for Adaptation in UK Urban Area, 33(1) Built environment 46 (2007).

${ }^{4}$ See for instance Robbert Biesbroek et al., Europe Adapts to Climate Change: Comparing National Adaptation Strategies, 20 Global Environmental Change 440 (2010).

${ }^{5}$ While there are many definitions for "green infrastructure", we have used the following definition: "an interconnected network of green spaces that conserves natural ecosystems values and functions and provides associated benefits to human populations", provided by Mark A. Benedict and Edward T. McMahon, Green Infrastructure: Smart Conservation for the 21st Century, Sprawl Watch Clearing House Monograph Series, Washington DC, at 5 (undated).

${ }^{6}$ Diane E. Bowler et al., Urban greening to cool towns and cities: A systematic review of the empirical evidence, 97 Landscape and Urban Planning 147 (2010).

${ }^{7}$ Susannah E. Gill et al., Adapting cities for climate change: the role of the green infrastructure, 33(1) Built Environment 115 (2007).
} 
adaptation and mitigation benefits, green infrastructure offers a range of other benefits, such as increase in amenity value, attraction of investment, increase in property value, reduction of noise and air pollution, and health benefits. This makes green infrastructural planning an attractive no-regrets adaptation strategy, since it additionally contributes to sustainable development of urban areas. ${ }^{8}$

Nevertheless, green adaptation measures require space, and this represents a major challenge, since urban areas are under continuous development pressure and generally have scarce land resources. Integrated responses at the local level are desirable, and this is typically where urban planning could play an important role in mediating competing demands for land use. ${ }^{9}$ Among European national governments there appears to be a common recognition of the role of urban planning in adaptation. ${ }^{10}$ Urban planning, through its effect on land use and spatial configurations in cities, can affect vulnerability to the impacts of climate change. ${ }^{11}$ Urban planning could reduce this vulnerability by designating (new) land for green space. However, in Europe the integration of adaptation considerations into urban planning still appears to be limited to the general level of policy formulation and lacks concrete instruments and measures for actual implementation on the ground. ${ }^{12}$ Based on an extensive literature study of publications that address urban climate

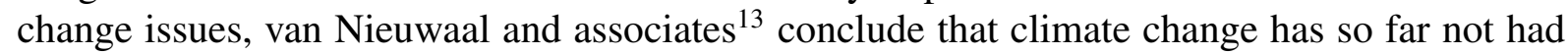
much impact on urban planning, and that extensive knowledge of practical experience still needs to be developed.

Given the important role urban planning could play in the governance of adaptation, it is unfortunate that the capacity to do so is still underdeveloped. Although the link between capacity and actual adaptation action is not yet well understood, we assume that the capacity of urban planning is an important precondition for the successful governance of adaptation, and ultimately for the effectiveness of green space as an adaptation measure. This article aims to analyse the capacity of cities for climate greening - that is, for adapting to climate change by means of green space-through the concept of "governance capacity". We define governance capacity as the degree to which a public-private network of actors is able to resolve societal issues, in particular, climate-adaptation issues.

\footnotetext{
${ }^{8}$ See for instance Tüzin Baycan-Levent and Peter Nijkamp, Planning and Management of Urban Green Spaces in Europe: Comparative Analysis, 135(1) Journal of Urban Planning and Development 1 (2009); and Philip James et al., Towards an integrated understanding of green space in the European built environment, 8 Urban Forestry \& Urban Greening 65 (2009).

${ }^{9}$ Lindley et al., supra note 3.

${ }^{10}$ Per Mickwitz et al., Climate Policy Integration, Coherence and Governance, Partnership for European Environmental Research (PEER), Report No. 2 (2009).

${ }^{11}$ Simin Davoudi, Jenny Crawford, and Abid Mehmood (eds.), Climate Change and Spatial Planning Responses, in Planning For Climate Change: Strategies for Mitigation and Adaptation for Spatial Planners 7 (Simin Davoudi, Jenny Crawford, and Abid Mehmood, eds., Earthscan, 2009).

12 Mickwitz et al., supra note 10.

${ }^{13}$ Kim van Nieuwaal et al., A State of the Art of Governance Literature on Adaptation to Climate Change: Towards a Research Agenda, Knowledge for Climate report 003 (2009). Available at <www.klimaatonderzoeknederland.nl>.
} 
We have attempted to build knowledge on the governance of adaptation to climate change through an in-depth comparative case study of three frontrunners in adaptation: London, Rotterdam, and Toronto. The comparison achieves general insights into relevant capacities of cities for climate-greening the urban environment, as well as insights into the main development areas of these capacities, based on the experiences of these cities. Our research has focused on planned adaptation: those policy initiatives that are pro-actively planned over a longer period of time, as opposed to those that happen spontaneously in the regular course of events, also referred to as autonomous adaptation. ${ }^{14}$ This means that there is an inherent bias towards the role of public bodies (urban planning authorities) as primary producers of a public good, such as climate adaptation measures, although the importance of private actors in urban planning processes has become evident in our research. The research question addressed here is: What is the governance capacity of cities to adapt to climate change through urban green planning, and what are the key barriers to, and opportunities for, this capacity?

Section two of this article discusses the framework developed to analyse and compare the governance capacity across the three cities. In section three, the research method is briefly described. Section four gives an overview of the three cities and their activities with regard to adaptation planning. Section five discusses the main results regarding their practice in adaptation planning, and section six provides the conclusions of our research.

\section{Governance Capacity Framework}

Our point of departure is Nelissen's concept of administrative capacity. ${ }^{15}$ Nelissen developed the "JEP triangle", ${ }^{16}$ based on three administrative-science approaches. The juridical approach represents the law and general principles of good governance; its values are justice, legality, and the rule of law. The economic-managerial approach involves the effective use of businessmanagement tools for public policy, with values such as effectiveness, efficiency, and simplicity. The political approach concerns democratic arrangements, and involves values such as societal support, political representation, accountability, and transparency. With this three-dimensional tool, a governance arrangement can be analysed, for instance, for its fairness, effectiveness, and legitimacy. The governance challenge lies in balancing these multiple, partly oppositional approaches. ${ }^{17}$

We interpret legal capacity as those formal regulations and policy principles which urban planning has at its disposal to steer adaptation planning by means of green space, both in the protection of existing green space and in the creation of new such space. Regulations and policies are critical

\footnotetext{
${ }^{14}$ Hans-Martin Füssel, Adaptation planning for climate change: concepts, assessment approaches, and key lessons, 2 Sustainability Science 265 (2007).

${ }^{15}$ Nico Nelissen, The Administrative Capacity of New Types of Governance, 2 Public Organization Review: A Global Journal 5 (2002).

${ }^{16}$ Nelissen, supra note 15 , at 5 .

${ }^{17}$ Ibid.
} 
because they can prevent urban environments from becoming even more impermeable, blocking the diffusion of surface water (from heavy rainfall for instance) into the ground. Rules to protect and enhance green space should thus decrease the vulnerability to surface water run-off, by retaining and storing rainwater, and to heat stress, by providing shading and evaporative cooling. The assumption is that the more numerous and stronger these rules and policies are, the higher the legal capacity to adapt the urban environment to excessive rainfall and temperatures.

Regarding managerial capacity, we have looked at the extent of integration of adaptation into urban planning, the extent of collaboration with other policy sectors, and the use of integrative management tools as a means for effective governance of adaptation. With respect to the first critical aspect of integration, there appears to be scientific consensus that adaptation should not be dealt with as a stand-alone issue, but demands an integrated approach: it should be mainstreamed into the policies, programs, and processes of other policy fields. ${ }^{18}$ Therefore, the assumption is that the extent of integration influences the effectiveness of urban planning: the more it is integrated into urban-planning documents and processes, the better urban planning is able to climate-green a city. The second critical aspect concerns the organization of urban planning, green planning, and adaptation planning. To facilitate the integration of adaptation into urban planning and other relevant policy sectors, interaction is necessary among governance levels, and among actors, stakeholders, and policy sectors. It is assumed that the level of coordination across policy sectors, governance levels, and geographical areas influences the effectiveness of urban, green, and adaptation planning - the more horizontal and vertical coordination, the better. Likewise, the extent of fragmentation of these policy fields determines effectiveness-the more fragmented they are, the more coordination is needed. The third critical aspect concerns the use of management tools and strategies. The idea behind this is that the public sector can learn from the business sector about how to efficiently govern a public issue. ${ }^{19}$ The assumption is that the use of management strategies and tools, such as project teams, committees, task forces, and partnerships, will increase the cooperation among relevant actors and stakeholders and thus increase efficiency - the more these strategies and tools are applied, the higher the managerial capacity of urban planning to climate-green the urban environment will be.

We have broken political capacity down into the three critical aspects of accountability, political will, and leadership. Accountability is a key requirement of any governance arrangement, and has been made specific in this research by focusing on the processes of adaptation planning: we hypothesize that the more open and transparent these processes are, and the more active engagement there is from stakeholders and the public, the higher the political capacity of city administrations will be. The second aspect, political will, is necessary for gaining the societal support to develop and implement adaptation policies, and for effective integration of adaptation

\footnotetext{
${ }^{18}$ See for instance Robbert Biesbroek et al., Europe adapts to climate Change: Comparing National Adaptation Strategies, 20(3) Global Environmental Change 440 (2010); Hans-Martin Füssel, Adaptation planning for climate change: concepts, assessment approaches, and key lessons, 2 Sustainability Science 265 (2007); and W. Neil Adger, Nigel W. Arnell, and Emma L. Tompkins, Successful adaptation to climate change across scales, 15 Global Environmental Change 77 (2005).

${ }^{19}$ Nelissen, supra note 15 .
} 
into related policies. ${ }^{20}$ It is considered necessary for the development and implementation of urban planning strategies that take adaptation into account. ${ }^{21}$ We assume that the higher the political support for adaptation planning by policymakers and politicians, and the longer it is maintained, the higher will be the political capacity. Leadership is seen as another important aspect of the capacity of institutions to adapt to climate change. ${ }^{22}$ The stronger the leadership, the higher the political capacity of city administrations to promote change.

While these capacities, as derived from the JEP triangle, are relevant, our analytical framework is complemented by two additional capacities that are mentioned in the literature. We have been particularly inspired by the literature concerning "adaptive capacity". Adaptive capacity originates in the literature on socio-ecological systems, and generally refers to a system's ability to adapt or cope with change. ${ }^{23}$ In the context of climate change, the IPCC has defined adaptive capacity more narrowly as "the ability of a system to adjust to climate change (including climate variability and extremes), to moderate potential damages, to take advantage of opportunities, or to cope with the consequences." 24

First, we add resource capacity, since this is regarded as a critical factor in the literature on adaptive capacity ${ }^{25}$ and green planning in urban areas. ${ }^{26}$ Resource capacity contains critical aspects in the form of economic, human, and knowledge resources. It is obvious that sufficient resources are needed for dealing with adaptation, just like any other governance issue. Money is a basic resource for any activity. Nevertheless, we find in particular the know-how of planning staff, the available knowledge, and the support of external experts, to be critical for the resource capacity in light of the uncertainty surrounding climate change.

Second, we add learning capacity to the framework as the fifth and last sub-capacity. It appears to be quite crucial in the literature on adaptive capacity, since learning is regarded as essential for the ability of social-ecological systems to cope with change and adjust accordingly. ${ }^{27} \mathrm{We}$

\footnotetext{
${ }^{20}$ Mickwitz et al., supra note 10.

${ }^{21}$ Elizabeth Wilson, Adapting to Climate Change at the Local Level: The Spatial Planning Response, 11(6) Local Environment 609 (2006).

${ }^{22}$ See for instance Joyeeta Gupta et al., The adaptive Capacity Wheel: a method to assess the inherent characteristics of Institutions to enable the adaptive capacity of society, 13 Environmental Science and Policy 459 (2010); and Shagun Mehrotra et al., Framework for City Climate and Risk Assessment. Buenos Aires, Delhi, Lagos, and New York, prepared for the World Bank's 5th Urban Research Symposium Cities and Climate Change: Responding to an Urgent Agenda, Marseille, 28-30 June 2009.

${ }^{23}$ See, for instance, Claudia Pahl-Wostl, A conceptual framework for analysing adaptive capacity and multi-level learning processes in resource governance regimes, 19 Global Environmental Change 354 (2009); and W. Neil Adger, Nigel W. Arnell, and Emma L. Tompkins, Successful adaptation to climate change across scales, 15 Global Environmental Change 77 (2005).

${ }^{24}$ Climate Change 2007: Impacts, Adaptation and Vulnerability, Summary for Policy Makers, at 21, contribution of Working Group II to the Fourth Assessment Report of the Intergovernmental Panel on Climate Change (IPCC).

${ }^{25}$ Gupta et al., supra note 21; Ellen Wall and Katia Marzall, Adaptive Capacity for Climate Change in Canadian Rural Communities, 11(4) Local Environment 373 (2006).

${ }^{26}$ Baycan-Levent and Nijkamp, supra note 8.

${ }^{27}$ Gupta et al., supra note 21; Pahl-Wostl, supra note 23.
} 
formulate its two critical aspects as "dealing with uncertainty" and the presence of "continuous learning processes". The first aspect, uncertainty, is regarded as a key constraint to the governance of adaptation. ${ }^{28}$ We pay attention to how uncertainty is framed, how uncertainty is reduced through technological approaches, and how uncertainty is managed through more innovative approaches. The assumption is that the higher the extent to which uncertainty is explicitly dealt with through the approaches mentioned above, the higher the learning capacity will be. With respect to the aspect of continuous learning, we expect that the greater the extent of existing infrastructure for the distribution and safeguarding of knowledge, the greater the exchange of experiences facilitated through internal and external networks, and the more frequent the utilization of stakeholder dialogue to enhance learning, the higher will be the learning capacity.

The five sub-capacities and their critical aspects are the building blocks of the analytical framework of this paper, as represented in Fig. 1. The inner circle represents a general framework for the governance capacity for adaptation. We have used the concept of "governance capacity" instead of "administrative capacity" to put greater emphasis on the importance of the involvement of non-state actors alongside state actors in the governance of adaptation. ${ }^{29}$ The outer circle represents a specific application of the framework the climate-greening of cities. A detailed set of indicators has been used to measure each critical aspect. Each indicator has been scored against a fixed set of three parameters, which provided a rating of weak, medium, or strong. ${ }^{30}$

Nelissen made a distinction between potential capacity and effective capacity in terms of actual performance. ${ }^{31}$ Considering that adaptation policy is in a developmental stage, it is still too early to study actual capacity. Therefore, we have focused on potential capacity. This means that our analysis is based on policy intentions, as expressed in policy documents and as derived from interviews with stakeholders. The objects of our analysis are urban-planning authorities and their urban-planning activities, with a focus on green-space measures from small to large scale (green roofs, trees, parks, green infrastructure) in the realization that they can only form part of the solution to addressing the impacts of climate change. The framework has been applied to public and private actors who are involved in policies and programs that are meant to adapt the local urban environment through the use of green spaces.

\footnotetext{
${ }^{28}$ See, for instance, W. Neil Adger et al. Are there social limits to adaptation to climate change?, 93 Climatic Change 335 (2009); and Hans-Martin Füssel, supra note 14.

${ }^{29}$ Inspired by Nelissen's work, Bas Arts \& Henri Goverde have defined governance capacity as "the extent to which new forms of governance are able to successfully diminish or solve societal and administrative problems." Bas Arts and Henri Goverde. The governance capacity of (new) policy arrangements: A reflexive approach, at 75, in Institutional Dynamics in Environmental Governance (Bas Arts and Pieter Leroy, eds, 2006).

${ }^{30}$ A detailed account of the analytical framework as well as the rating of the indicators used can be found in Heleen Mees, Climate Greening London, Rotterdam and Toronto: A comparative analysis of the governance capacity of adaptation to climate change in urban areas (2010) (unpublished MA Thesis, University of Utrecht, available at $<$ http://igitur-archive.library.uu.nl/student-theses/2010-0507-200245/UUindex.html>).

${ }^{31}$ Nelissen, supra note 15 .
} 


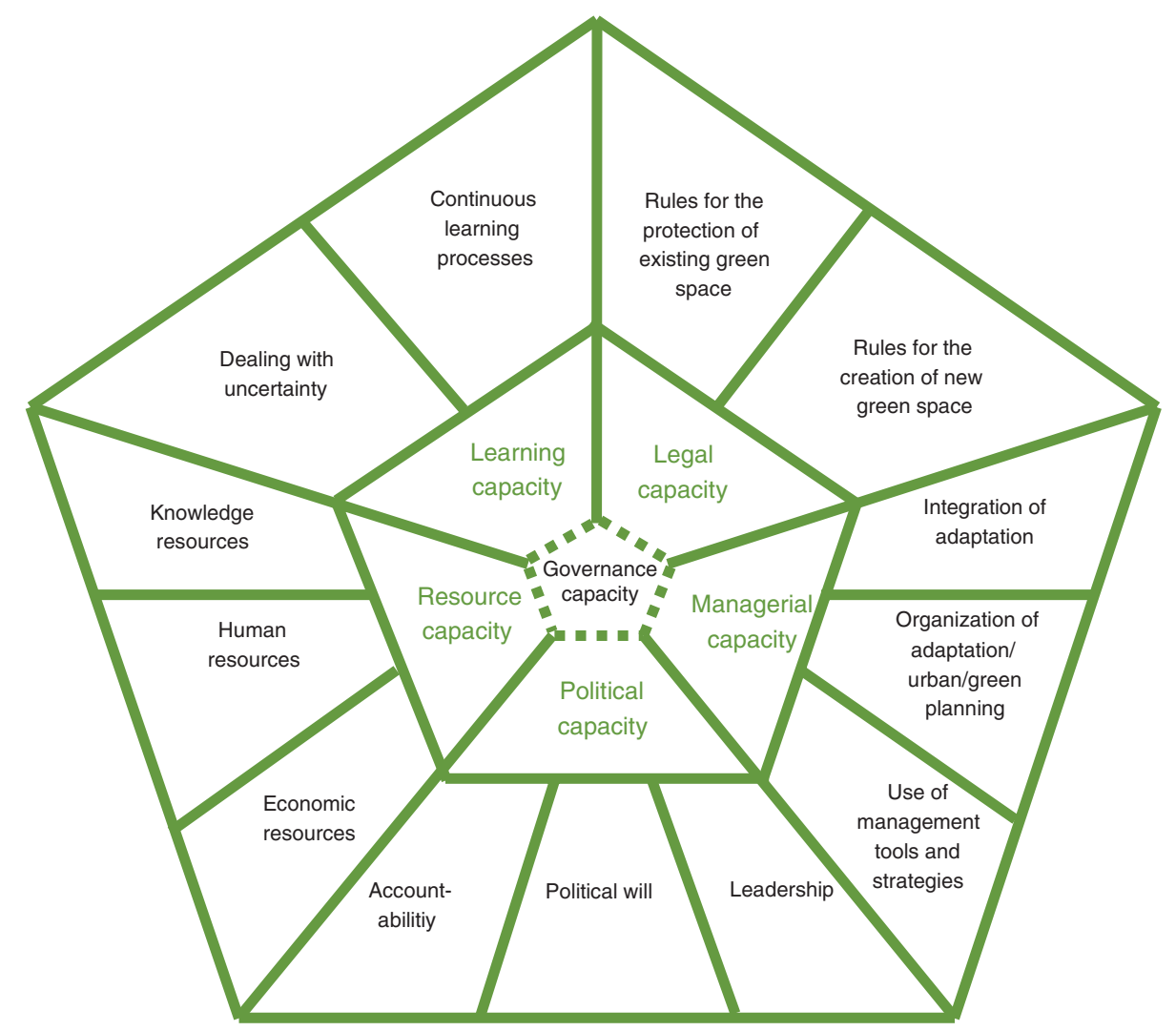

Fig. 1. Framework for the analysis of governance capacity inspired by Nelissen ${ }^{32}$ and Gupta et al. ${ }^{33}$

\section{RESEARCH METHOD}

The method applied is a qualitative cross-national comparative case-study approach. This is a commonly used strategy in spatial planning literature to increase the validity of the research. ${ }^{34}$ First, through desk research, we studied the contexts in which the selected cities operate by conducting a review of the (national/provincial) planning systems they are subject to, as well as the adaptation policies from higher levels of government that might provide guidance on adaptation policies at the local/municipal level. Second, an in-depth study was conducted of the governance capacity of each city, after which the cities' capacities were compared and contrasted for similarities and differences, so that existing patterns could be identified. Two methodological approaches were applied, as described by Urwin and Jordan. ${ }^{35}$ A top-down perspective was provided through a content analysis of ninety-five official policy and legal documents in the field

${ }^{32}$ Nelissen, supra note 15 .

${ }^{33}$ Gupta et al., supra note 22.

${ }^{34}$ Olivier Sykes, The Importance of Context and Comparison in the Study of European Spatial Planning, 16(4) European Planning Studies 537 (2008).

${ }^{35}$ Kate Urwin and Andrew Jordan, Does public policy support or undermine climate change adaptation? Exploring policy interplay across different scales of governance, 18 Global Environmental Change 180 (2008). 
of adaptation, urban planning, water management, and urban greening. ${ }^{36}$ These documents made by policy makers at the top contain rules and policies that give direction and set objectives that should lead to adaptive action on the ground. This source was complemented with a bottom-up perspective, provided by conducting thirty-three semi-structured interviews with key actors and stakeholders in the three cities (officers of various government divisions, such as urban planning, water management, environmental policy, urban forestry/green planning, and health services; as well as representatives of NGOs and industry), and six "helicopter" interviews with experts, aiming to benefit from their overview of the field of urban planning and governance. This bottomup approach provides additional insights as to how the goals in policy documents are translated on the ground, by drawing upon the expertise and experience of various sectoral actors in the public and private sphere. The different perspectives of these respondents gave a good overview of the practice of climate-greening on the ground. In-depth case-study descriptions were sent to respondents for factual verification.

\section{The Three Case Studies}

London, Rotterdam, and Toronto were selected because of a number of commonalities. As Western democratic cities, they are exposed to similar processes of globalization, neo-liberalization, and an ever-increasing concern for sustainable development. They face similar impacts from climate change, leading to risks of urban flooding and heat stress due to the intensification of the UHI effect. ${ }^{37}$ Compared to other cities, they are activist: in 2008 each city created a crossdivisional policy dedicated to adaptation, and since then these cities have started to implement (green) adaptation measures. Their growth is contained through green-belt and compact-city policies, ${ }^{38}$ making them subject to similarly high densification pressure. They belong to the C40 Cities Climate Leadership Group, ${ }^{39}$ a trans-national network headed by the Mayor of Toronto. Table 1 provides an overview of the main differences of the urban-planning governance arrangements that apply in these cities, which are relevant to us. We hope that through our selection of these three cases lessons can be learned from the experience of cities with a common agenda but with different governance and planning contexts.

\section{London}

The United Kingdom has traditionally been a centralized, unitary state and has had a rather topdown approach to planning, with the central government exercising considerable influence on

\footnotetext{
${ }^{36}$ A detailed list of legal and policy documents is available in Mees, supra note 30.

${ }^{37} \mathrm{Cities}$ are on average $4^{\circ} \mathrm{C}$ warmer than rural areas because the built environment tends to attract and retain warmth which is gradually released back into the atmosphere. See for instance S. J. Lindley et al., The Role of Spatial Risk Assessment in the Context of Planning for Adaptation in UK Urban Areas, 33(1) Built Environment 46 (2007). See also supra note 1.

${ }^{38}$ Maureen Carter-Whitney, Ontario's Greenbelt in an International Context. Comparing Ontario's Greenbelt to its Counterparts in Europe and North America, Friends of the Greenbelt Foundation Occasional Paper Series February 2008.

${ }^{39} \mathrm{C} 40$ is a group of large cities committed to tackling climate change. See <http://www.c40cities.org/>.
} 
Table 1 Overview of the main characteristics of urban-governance arrangements, made by the authors based on desk research

\begin{tabular}{|c|c|c|c|}
\hline Characteristics & London & Rotterdam & Toronto \\
\hline $\begin{array}{l}\text { Administrative } \\
\text { system }\end{array}$ & $\begin{array}{l}\text { centralized unitary } \\
\text { state }\end{array}$ & $\begin{array}{l}\text { decentralized unitary } \\
\text { state }\end{array}$ & federalized state \\
\hline Government levels & $\begin{array}{l}\text { national, regional } \\
\text { (Greater London } \\
\text { Authority), local } \\
\text { (33 boroughs) }\end{array}$ & $\begin{array}{l}\text { national, provincial, } \\
\text { municipal }\end{array}$ & $\begin{array}{l}\text { federal, provincial, } \\
\text { municipal }\end{array}$ \\
\hline \multirow[t]{2}{*}{ Spatial Planning Law } & $\begin{array}{l}\text { from UK national } \\
\text { government }\end{array}$ & $\begin{array}{l}\text { from Dutch national } \\
\text { government }\end{array}$ & $\begin{array}{l}\text { from Ontario } \\
\text { provincial } \\
\text { government }\end{array}$ \\
\hline & $\begin{array}{l}\text { Planning and } \\
\text { Compulsory } \\
\text { Purchase Act } 2004\end{array}$ & $\begin{array}{l}\text { Spatial Planning Act } \\
2008\end{array}$ & $\begin{array}{l}\text { Ontario Planning Act } \\
1990 \text { (last amended } \\
\text { 2009) }\end{array}$ \\
\hline $\begin{array}{l}\text { Planning } \\
\text { responsibility }\end{array}$ & Boroughs & $\begin{array}{l}\text { Municipality of } \\
\text { Rotterdam }\end{array}$ & $\begin{array}{l}\text { City of Toronto, } \\
\text { delegated by the } \\
\text { province }\end{array}$ \\
\hline \multirow[t]{2}{*}{ Main characteristics } & $\begin{array}{l}\text { no zoning plans } \\
\text { rather generic } \\
\text { policies which } \\
\text { leave room for } \\
\text { flexibility } \\
\text { traditional focus on } \\
\text { land-use planning; } \\
\text { since } 2004 \text { reform } \\
\text { more integrative }\end{array}$ & $\begin{array}{l}\text { zoning plans } \\
\text { rather strict policies } \\
\text { that regulate land } \\
\text { use prior to } \\
\text { decision-making } \\
\text { very comprehensive } \\
\text { planning system }\end{array}$ & $\begin{array}{l}\text { zoning plans } \\
\text { rather strict policies } \\
\text { that regulate land } \\
\text { use prior to } \\
\text { decision-making } \\
\text { traditional focus on } \\
\text { land-use planning; } \\
\text { of late it is } \\
\text { becoming more } \\
\text { integrative }\end{array}$ \\
\hline & $\begin{array}{l}\text { public-private } \\
\text { partnerships }\end{array}$ & $\begin{array}{l}\text { public-private } \\
\text { partnerships }\end{array}$ & $\begin{array}{l}\text { public-private } \\
\text { partnerships }\end{array}$ \\
\hline \multirow[t]{2}{*}{$\begin{array}{l}\text { Policy guidance from } \\
\text { higher governments }\end{array}$} & $\begin{array}{l}\text { National Planning } \\
\text { Policy Statements } \\
\text { (PPS) }\end{array}$ & $\begin{array}{c}\text { National Spatial } \\
\text { Strategy } 2004\end{array}$ & $\begin{array}{r}\text { Provincial Policy } \\
\text { Statement } 2005\end{array}$ \\
\hline & $\begin{array}{l}\text { Greater London } \\
\text { Authority's London } \\
\text { Plan }\end{array}$ & $\begin{array}{l}\text { National Structure } \\
\text { Vision for the } \\
\text { "Randstad" } \\
\text { Provincial Structure } \\
\text { Vision }\end{array}$ & \\
\hline
\end{tabular}

planning processes. However, in the last decade, powers over some aspects of domestic policy, such as planning, have been devolved to Scotland, Wales, and Northern Ireland. Within England, the devolution of decision-making has given London unique powers to govern itself. ${ }^{40}$ London

\footnotetext{
${ }^{40}$ Nick Bailey, Managing the Metropolis. Economic Change, Institutional Reform and Spatial Planning In London, in Conceptions of Space and Place in Strategic Spatial Planning (S. Davoudi and I. Strange, eds., 2009).
} 
has a two-tier government structure: the regional body, called the Greater London Authority, consisting of the Mayor and an Assembly that scrutinizes the Mayor's work, and the local authorities, consisting of thirty-three boroughs. The Greater London Authority Acts of 1999 and 2007 have given London a number of powers which are exclusive to the city; one of them is the power to create a Regional Spatial Strategy in the form of the London Plan. ${ }^{41}$ It is the integrating framework for all Mayoral strategies. It gives strategic guidance to the development of London, and gives the boroughs direction in their planning policies and processes. ${ }^{42}$ Climate policy has been a key political priority in Mayoral strategies, and adaptation has moved up the agenda since the publication of the Draft Adaptation Strategy in 2008. ${ }^{43}$ Although flood risk is a major driver of adaptation, heat stress has become more important after the heat waves of 2003 and 2006. Mitigation and adaptation are key themes in the London Plan. The Urban Greening Program (consisting of a green-roof policy, a tree-planting program, and the establishment of an urbanwide green grid) is an essential part of the adaptation strategy, which has been integrated into the London Plan. ${ }^{44}$ Green roofs are required on all major developments. The current Mayor, Boris Johnson, claims to be committed to increasing the amount of green surface area in inner London for adaptation purposes. ${ }^{45}$ Figure 2 provides a more detailed overview of London's adaptation policies.

\section{Rotterdam}

The Netherlands is a decentralized unitary state. Local governments (municipalities) have planning responsibility and produce legally binding zoning plans. There is a strong tradition of consultation among different government levels, ${ }^{46}$ but it is said that Dutch planning is led by municipalities using "informal ways of using formal rules". ${ }^{47}$ The primary urban-planning policy document of the municipality of Rotterdam, from 2007, is its City Vision 2030. ${ }^{48}$ Although it does not mention adaptation explicitly, strategic guidance is given on water retention, which historically is the main adaptation concern for both Rotterdam as a delta city and the country as a whole. Adaptation considerations have been addressed separately in the Rotterdam Climate-

\footnotetext{
${ }^{41}$ The London Plan: Spatial Development Strategy for Greater London-Consolidated with Alterations since 2004, Greater London Authority, Mayor of London (2008).

42 Bailey, supra note 40 .

${ }^{43}$ The original adaptation strategy was published in August 2008 as The London climate change adaptation strategy: Draft report. An updated version was published in February 2010 as The draft climate change adaptation strategy: Public Consultation Draft, Greater London Authority, Mayor of London (2010).

${ }^{44}$ The London Plan, supra note 41.

${ }^{45}$ The London Plan: Spatial Development Strategy for Greater London-Consultation draft replacement plan, Greater London Authority, Mayor of London, at 13 (2009).

${ }^{46}$ Anne G. Busck, et al., Planning approaches for "rurban" areas: Case studies from Denmark, Sweden and the Netherlands, 109(1) Danish Journal of Geography 15 (2008).

${ }^{47}$ Vincent Nadin and Dominic Stead, European Spatial Planning Systems, Social Models and Learning, 172(1) disP 35, at 42 (2008).

${ }^{48}$ Rotterdam City Vision (Stadsvisie Rotterdam. Ruimtelijke Ontwikkelingsvisie 2030), not available in English, Municipality of Rotterdam (2007).
} 
Adaptation policy development and implementation in London

Most important adaptation policies:

- Green roof policy through the London Plan (Mayor of London/Greater London Authority).

- Urban Greening Programme through the London Plan and Draft Adaptation Strategy.

- Draft Adaptation Strategy (February 2010, Mayor of London/Greater London Authority).

- Draft Water Strategy (August 2009, Mayor of London/Greater London Authority).

- A few boroughs have issued their own adaptation strategy, for example City of London Corporation and Islington.

Most important adaptation activities and research projects (executed or in execution phase):

- London Climate Change Partnership, headed by the Greater London Authority (since 2002).

- UKCIP: UKCP09 with localized climate projections for London and "the Brain".

- Tree-planting programme and Priority Parks Programme by Mayor Johnson.

- Borough initiatives, with Islington being most active with a dedicated adaptation officer. See http://www.islington.gov.uk/environment/sustainability/sus_building/buildings_climate.asp.

Most important future policy intentions for adaptation relevant to this article:

- Concerning green roofs: Study on, and implementation of, a green roof incentive programme for the retrofitting of existing homes; prospectus on the benefits of green roofs.

- To manage temperatures by increasing green space in the city: enhance 1,000 hectares of green space; prepare supplementary guidance for a London-wide green grid; increase green cover in the Central Activities Zone.

- Restoration of 15 kilometers of London's rivers.

- Lobby the government to amend building regulations to require buildings that are being rebuilt or renovated to be climate-resilient.

For more information on London's adaptation strategy and activities, see

$<$ http://www.london.gov.uk/climatechange/strategy $>$ and $<$ http://www.london.gov.uk/lccp/>. For a more complete overview, see the Draft Adaptation Strategy, available from

$<$ http://www.london.gov.uk/climatechange/sites/climatechange/staticdocs/Climiate_change_adaptation.pdf)>.

Fig. 2. Overview of London's adaptation policies.

Proof Adaptation Programme ${ }^{49}$ and "Water Plan 2". ${ }^{50}$ Water management is seen as the dominant means of climate-proofing the city and simultaneously transforming it into an attractive place to live. Green roofs are a popular green-space adaptation measure for retaining rainwater. They are incorporated into the City Vision, the Adaptation Programme, and the Water Plan, and are promoted by an extensive incentive scheme. Figure 3 provides more detail on Rotterdam's adaptation policies.

\section{Toronto}

Canada is a federal state in which the federal government has no direct planning authority. The seven provinces are the most important level of government for this purpose. Municipalities are

${ }^{49}$ Rotterdam Climate Proof, Adaptation Programme 2009: The Rotterdam Challenge on Water and Climate Adaptation, English version, Municipality of Rotterdam (2009).

${ }^{50}$ Waterplan2: Working on water for an attractive city, English version, a joint product by the Municipality of Rotterdam and the Water Boards Waterschap Hollandse Delta, Hoogheemraadschap van Schieland en de Krimpenerwaard and Hoogheemraadschap van Delfland (2007). 
Adaptation policy development and implementation in Rotterdam

Most important adaptation policies:

- Integrated water management policy in Water Plan 2 and related policies.

- Formulation of a specific adaptation strategy and programme.

Most important adaptation activities and research projects (executed or in execution phase):

- Green Roof incentive programme since 2008.

- Establishment of a separate group of six officers for adaptation, "Rotterdam Climate Proof".

- Innovative experiments with multi-functional land-use forms: floating pavilion, water plaza, and roof park dike as testing grounds.

- Installation of a Climate Campus.

- UHI research project.

- Development of a Climate Atlas, Route Planner, and Barometer.

- International branding of Rotterdam as the Climate City through exhibitions and conferences.

Most important future policy intentions for adaptation:

- Formulation of a specific policy for green roofs.

- Making green roofs mandatory on all city-owned buildings in the case of new development or redevelopment.

- Integration of adaptation goals in all urban planning processes by 2012 .

For more information see

$<$ http://www.rotterdamclimateinitiative.nl/documents/RCP/English/RCP_folderalgemeen_eng.pdf>,

$<$ http://www.rotterdamclimateinitiative.nl/documents/RCP/English/RCP_adaptatie_eng.pdf $>$, and

$<$ http://www.rotterdamclimateinitiative.nl/nl/rotterdam_climate_initiative/english/mission_ambition $>$.

Fig. 3. Overview of Rotterdam's adaptation policies.

the "creatures of the provinces", 51 as they do not have constitutional rights. ${ }^{52}$ The City of Toronto Act 2007 gave the city council and Mayor limited administrative powers, mainly for creating taxes to generate funds for policy programs. ${ }^{53}$ Planning authority lies with the provinces, which in turn delegate it to the municipalities through Municipal and Planning Acts, while maintaining supervision. ${ }^{54}$ Zoning is an important aspect of spatial planning for determining the arrangement of land uses. ${ }^{55}$ Municipalities are responsible for preparing a detailed spatial plan (often called the Official Plan), for adopting detailed by-laws to regulate zoning, building, and environmental regulations, as well as for implementing them. ${ }^{56}$ Toronto has its own "Official Plan", 57 which was approved in 2007. Although climate change is not specifically mentioned in the Official Plan,

${ }^{51}$ Edward J. Levy, Public Transport in the Toronto: Region History and Prospects Urban Planning Overseas, special issue on urban planning in Toronto 51, at 63 (2005).

52 Jeanne M. Wolfe, Planning in Canada: The Framework, Urban Planning Overseas, special issue on urban planning in Toronto 1 (2005).

53 Julie-Anne Boudreau, Roger Keil, and Douglas Young, Changing Toronto. Governing In-Between the Global and the Local (University of Toronto Press, 2009).

54 Wolfe, supra note 52.

55 Ontario Professional Planners Institute, Who We Are, What We Do, and What We Have Accomplished, A presentation created for World Town Planning Day, available at $<\mathrm{http} / / / \mathrm{www}$.ontarioplanners.on.ca/default.aspx $>$.

${ }^{56}$ Wolfe, supra note 52.

${ }^{57}$ Toronto Official Plan. Consolidated August 2007, City of Toronto (2007). 
Adaptation policy development and implementation in Toronto

Most important adaptation policies (including those not labelled as such):

- Hot Weather Response Plan and related Heat Health Alert System.

- Wet Weather Flow Management Policy and related policies for stormwater retention.

- Policy to double the tree canopy and related tree-planting programmes.

- Green Roof by-law mandating green roofs on all large developments (as of 31 January 2010).

- Toronto Green Standard for all newly built dwellings (as of 31 January 2010).

Most important adaptation activities and research projects (executed or in execution phase):

- Green Roof incentive programme.

- TRCA's Greenland Acquisition Project and Municipal Response Plan.

- Creation of the Toronto Urban Climate Change Network.

- UHI study and Heat Vulnerability Assessment.

- Climate Driver Study (expected by 2010/2011).

- 2010 Forest Inventory and Tree Canopy study by Toronto Urban Forestry.

Most important future policy intentions for adaptation:

- Running of climate change risk assessment processes for all relevant city divisions, starting with the Transportation Services Division.

- Development of a long-term and comprehensive adaptation strategy.

- Integration of adaptation into all relevant city-planning processes.

For more information, see <http://www.toronto.ca/teo/adaptation.htm>.

Fig. 4. Overview of Toronto's adaptation policies.

heat stress and stormwater run-off are important themes. Through its Climate Change Action Plan $2007,{ }^{58}$ the city committed itself to doubling the tree canopy by 2050 in order to combat heat stress and air pollution, reduce urban flooding, and sequester carbon. In 2008, the city issued its comprehensive adaptation strategy "Ahead of the Storm". ${ }^{59}$ Its main recommendation was to incorporate climate change measures into the Official Plan, some of which are green infrastructural measures. A special green-roof by-law, effective since early 2010, makes green roofs mandatory for all new larger developments.$^{60}$ Figure 4 provides an overview of Toronto's adaptation policies.

\section{RESULTS}

\section{Legal Capacity}

\section{A. London}

The Greater London Authority (GLA) has developed many planning policies to protect existing green space. The new draft London Plan (LP) contains a policy on the establishment of a London-

${ }^{58}$ Change is in the air: Climate Change, Clean Air and Sustainable Energy Action Plan, City of Toronto (2007).

${ }^{59}$ Ahead of the storm: Preparing Toronto for Climate Change. Development of a Climate Change Adaptation Strategy, City of Toronto (2008).

${ }^{60}$ Toronto Municipal Code Green Roofs, Adopted by the Council of the City of Toronto 2009-05-27 by By-law No. 583-2009, City of Toronto (2009), available at http://www.toronto.ca/legdocs/municode/1184_492.pdf. 
wide Green Infrastructure, as a strategic network of open spaces. The LP also stipulates that each borough should produce an Open Space and a Tree Strategy. ${ }^{61}$ In addition, the GLA has developed several other planning documents for urban green planning to serve as guidance for the boroughs, such as the Supplementary Planning Guidance on the East London Green Grid, ${ }^{62}$ Best Practice Guidance on Open Space Strategies, ${ }^{63}$ and the Trees and Woodland Framework. ${ }^{64}$ In their turn, the boroughs designate open land in their jurisdictions through their Local Development Frameworks. Most of the smaller parks and recreational areas fall under the designation "Borough Open Land", which has a very high protection level. The boroughs also develop local policies (by-laws) to protect certain types of green spaces or trees.

The creation of new open space is usually part of a planning permission for a large development, negotiated by the borough. These kinds of deals are possible because of section 106 of the UK Town and Country Planning Act. ${ }^{65}$ This requires the developer to transfer land to the local authority, and in return the developer is granted planning permission. In addition, the new Community Infrastructure Levy ${ }^{66}$ is meant to give local authorities extra resources to invest in public services and social infrastructure, including green (open) space. Developers pay a charge, which local authorities must spend on local infrastructure to support the new development. Furthermore, several boroughs have adopted their Open Space Strategies as supplementary planning guidance. This mandates that all new developments create new open space. With respect to the GLA's efforts, the new draft LP contains a policy on urban greening. This policy contains a target to increase the amount of green surface area in central London by at least five per cent by 2030 and a further five per cent by $2050 .{ }^{67}$ Tree cover should be increased by five per cent by $2025 .^{68}$

\section{B. Rotterdam}

The protection of existing urban green space is predominantly a matter of the municipalities, which can designate green spaces in zoning plans to give them legal protection. The city-wide Rotterdam City Vision has embedded the city parks, district parks, and recreational green areas in its main structure of the public realm in order to protect them against development. ${ }^{69}$ Another municipal document relevant for protection of urban green is the Trees Structure Vision: it must be taken into account in development plans. ${ }^{70}$ The city also has a by-law to prohibit tree cutting.

${ }^{61}$ The London Plan: Consultation Draft replacement plan, supra note 45.

${ }^{62}$ Supplementary Planning Guidance: East London Green Grid Framework. London Plan, Mayor of London.

${ }^{63}$ Open Space Strategies. Best Practice Guidance. A Joint Consultation Draft by the Mayor of London and CABE Space, Mayor of London.

${ }^{64}$ Connecting Londoners with Trees and Woodlands. A Tree and Woodland Framework for London, Mayor of London.

${ }^{65}$ See $<$ http://www.legislation.gov.uk/ukpga/2004/5/contents>.

${ }^{66}$ The Community Infrastructure Levy, Department for Communities and Local Government, London.

${ }^{67}$ The London Plan: Consultation draft replacement plan, supra note 45.

${ }^{68}$ Leading to a Greener London. An environment programme for the capital, Mayor of London.

${ }^{69}$ Rotterdam City Vision, supra note 48.

${ }^{70}$ Bomenstructuurvisie Rotterdam, Municipality of Rotterdam. 
The provinces in the Netherlands have various means to create new green space through the expropriation of land and through public-private partnerships. The new national Land Development $\mathrm{Act}^{71}$ regulates the allocation of costs of land development. It creates the possibility for municipalities to demand the design and planning of open (green) spaces from developers in the case of new development or re-development. It thus provides municipalities with more ammunition in their dealings with private developers and housing corporations. ${ }^{72}$ Furthermore the water-management sector, which historically has strong regulatory power because of the huge flood risk in the Netherlands, also contains a regulation of interest to adaptation through green space. Ten per cent of the area of new development or re-development projects must be allocated for surface water retention within the area. This compensation norm is often realized through a combined green-blue solution, such as a canal with green borders, or through an entirely green solution, such as wadis.

\section{Toronto}

The protection of existing green space in Toronto is the primary responsibility of the municipal government. The City of Toronto is able to regulate development in a strict way through its Toronto Official Plan (TOP) ${ }^{73}$ and its accompanying secondary plans, zoning by-laws, and site plans. ${ }^{74}$ The TOP is considered to be a strong regulatory planning policy document that binds private land owners as well as the public authorities themselves. It restricts loss of green space in three ways. First, Toronto's growth is strictly contained within the abovementioned growth sites. Second, large sites of natural heritage or recreational value receive special protection under the Green Space System. Third, TOP designates "Parks and Open Space Areas", where development is generally prohibited. ${ }^{75}$ The City of Toronto is also very active in the protection of its seven million public and private trees. There are several Urban Forestry by-laws and policies in place to protect city-street trees, park trees, trees on private land, and trees in ravines. ${ }^{76}$

Under the Ontario Planning Act, in order to create new green space, municipalities may request five percent of the land from a residential development and two percent from other developments to be dedicated to parkland or public land for other recreational purposes. ${ }^{77}$ The TOP has adopted this regulation as the minimum norm, and has set a higher norm for priority areas. TOP also stipulates policies for cash-in-lieu options which are often applied in areas with higher densities. This compensation can be used to acquire parkland in the vicinity of the development. ${ }^{78} \mathrm{New}$

\footnotetext{
${ }^{71}$ The Land Development Act, new regulations for the development of building locations, English leaflet, Ministry of Housing, Spatial Planning and the Environment.

72 Ibid.

${ }^{73}$ Toronto Official Plan, supra note 57.

${ }^{74}$ Larry S. Bourne, The Challenge of Regional Planning in the Toronto Area: Past, Present and Future, Urban Planning Overseas, special issues on urban planning in Toronto 131 (2005)

75 Toronto Official Plan, supra note 57.

76 Toronto Urban Forestry By-laws \& Policies, <http://www.toronto.ca/trees/bylaws.htm>.

77 Planning Act. Ontario Ministry of Municipal Affairs and Housing.

${ }^{78}$ Toronto Official Plan, supra note 57.
} 
parkland is also generated through the efforts of the Toronto and Region Conservation Authority (TRCA), which has been running a "Greenlands Acquisition Project". ${ }^{79}$ Additionally, both the City of Toronto and TRCA have made substantial efforts to increase the tree canopy in Toronto. The city is committed to doubling its tree canopy from 17 to 34 per cent by 2050, and this initiative gained momentum when it was adopted as a climate mitigation and adaptation measure by the "Climate Change, Clean Air, and Sustainable Energy Action Plan" of 2007. ${ }^{80}$ Up to 100,000 trees are planted each year by the Urban Forestry division in cooperation with many partners. The TRCA also has a huge tree planting programme. In 2007 alone it planted more than 250,000 trees in the Greater Toronto Area. ${ }^{81}$ As one respondent said, "developing a tree culture is definitely on the rise." 82 As of 2010, Toronto has a by-law that mandates green roofs on every new building with a floor area greater than two thousand square metres. ${ }^{83}$

\section{Conclusion}

The research findings show that local authorities have many spatial regulations and policies at their disposal to protect existing and to create new green space. These are either devolved to them by higher tiers of government or created by the local authorities themselves. The legal capacity of these cities can therefore be judged as strong. However, the power of the development industry could undermine some of that potential in practice, as was mentioned by respondents in each city.

\section{Managerial Capacity}

\section{A. London}

With respect to integration of adaptation concerns, climate change is a primary issue for spatial planning in the UK, both nationally ${ }^{84}$ and at the London-wide level. The London Plan contains a separate chapter on climate change. The GLA's intention is to integrate adaptation into all policy documents, and it is promoting green space as a key adaptation measure. ${ }^{85}$ At the local level, though, with the exception of a few boroughs, when it comes to climate policy most urbanplanning processes still focus on mitigation. In integrating adaptation concerns, most attention is given to the issue of urban flooding. For instance, the Environment Agency is a statutory consultee for all developments in the London flood plain. As of late, the paving of front gardens

\footnotetext{
${ }^{79}$ Meeting the challenge of climate change. TRCA Action Plan for The Living City, Toronto and Region Conservation Authority.

${ }^{80}$ Change is in the air, supra note 58.

${ }^{81}$ Meeting the challenge of climate change, supra note 79.

82 Policy Officer, Toronto Environment Office, interviewed October 2009.

${ }^{83}$ Toronto Municipal Code Green Roofs, supra note 60.

${ }^{84}$ See for instance The Sustainable Communities Strategy, Department for Communities and Local Government; and Planning Policy Statement: Planning and Climate Change, supplement to Planning Policy Statement 1, Department for Communities and Local Government.

${ }^{85}$ The London Plan, supra note 61.
} 
larger than five square metres is permitted only if permeable materials are used, in order to reduce flood risk. ${ }^{86}$

With respect to organization, the responsibility for urban planning in London is dispersed horizontally across the boroughs and vertically across three government tiers: the Government Office for London (as the national government authority), the GLA, and the boroughs. This institutional fragmentation appears to be even more severe when it comes to green planning: each open (green) space in London is differently funded and owned. ${ }^{87}$ Relationships between the GLA and the boroughs can put a further strain on vertical coordination: the political party of the Mayor and the boroughs determine the extent of cooperation. Geographical coordination among thirty-three boroughs is difficult because they work quite independently and communicate poorly. Furthermore, coordination is constrained by party politics: boroughs of the same political party are more likely to work together. Apart from a fragmented governance landscape, horizontal coordination among policy departments is further impeded by compartmentalization due to a strong sectoral structure.

With respect to the use of management tools, the primary strategy employed for consolidating interests in London is through partnerships. In urban planning there are different constellations of public partnerships for the larger regeneration projects. Green planning is also increasingly carried out through partnerships, such as the East London Green Grid partnership and The London Parks and Green Spaces Forum. For adaptation planning there is a London Climate Change Partnership, which engages mostly in research and advice to policy makers. The Drain London Forum is a partnership of various public bodies looking at surface-water flooding, hotspots of high risk areas, and actions to remediate these risks.

\section{B. Rotterdam}

Regarding the integration of adaptation concerns, the Dutch government prescribes a dominant role to urban planning. Nevertheless, the Rotterdam City Vision is currently too abstract to contain enough guidance on adaptation. The vision-plan for the new city harbour area ("Stadshavens") is the first master plan to contain both mitigation and adaptation considerations. The so-called Water Plan 2 is the one that pays most attention to adaptation. Since water is such an important theme in Dutch society, national water policy obliges spatial planners to take water into account in their planning processes through the so-called "Water Test". This means that flood risk and water retention have to be considered. At the municipal level there are currently no provisions in place for automatically including adaptation in the standard planning processes and procedures-the organizational structure for that is still lacking. The central goal of Rotterdam Climate Proof (RCP) is to ensure that adaptation is integrated into urban-planning processes and considered in every policy division in the city by 2012 . As one RCP officer said, "our main purpose is to make

\footnotetext{
${ }^{86}$ Guidance on the permeable surfacing of front gardens, Department for Communities and Local Government.

${ }^{87}$ Staff member, London Parks and Green Spaces Forum, interviewed November 2009.
} 
ourselves obsolete". ${ }^{88}$ In order to facilitate this integration, the RCP has developed several tools, such as a climate guide and climate barometer for urban planning. The RCP is also developing the so-called "RAS method", 89 meant to integrate adaptation measures into urban planning at different spatial scales. Green planning for adaptation is limited to green roofs for water retention, although a Climate and Green Toolbox is being developed to facilitate the climate-greening of Rotterdam.

The organization of urban planning is dispersed across different agents, horizontally within the municipality (among three city divisions responsible for the physical environment) as well as vertically. Hence, issues of institutional fragmentation and compartmentalization dominated the interview responses in terms of perceived barriers to the integration of adaptation. In stark contrast, adaptation planning remains primarily in the hands of one municipal body, the RCP. This was a deliberate strategy to avoid fragmentation in the early stages, with the ultimate goal of mainstreaming adaptation into existing policy fields after maturation.

Rotterdam is experimenting with new management tools and strategies to improve horizontal coordination. One such strategy is the creation of a Project Management approach. ${ }^{90}$ Other tools include the use of workshops, brainstorming sessions, and other policy forums that bring stakeholders together. Another way to promote the integration of social, economic, and environmental concerns into urban planning is through multi-functional forms of land use, such as green roofs, water plazas, and green cable-car lanes. Rotterdam is currently developing a multi-functional dike (Dakpark Rotterdam) with a district park, a commercial centre, and parking. ${ }^{91}$

\section{Toronto}

When it comes to the integration of adaptation concerns, policy documents at the provincial level of Ontario do not yet contain explicit adaptation considerations. At the municipal level, the Toronto Official Plan (TOP) deals with the management of stormwater, land-use planning for flood mitigation, and the use of green spaces to reduce the UHI effect. A key recommendation in the Adaptation Strategy was to ensure that explicit goals for adaptation be incorporated into the review of the TOP. ${ }^{92}$ The TRCA is involved in formal site-plan approvals in valley and stream corridors and wetlands. The Ontario Municipal Act provides that municipalities consult the TRCA on their zoning and official plans. The TRCA has a separate planning-anddevelopment department for these regulatory functions. At the municipal level, inclusion of adaptation planning in planning processes has taken a substantial step forward as a result of the

\footnotetext{
88 Policy Officer, Rotterdam Climate Proof, interviewed September 2009.

${ }^{89}$ De Rotterdamse Klimaatadaptatie Strategie, see <http://www.rotterdamclimateinitiative.nl/nl/100_ klimaatbestendig/projecten/rotterdamse_klimaatadaptiestrategie_(ras)?portfolio_id=36>.

${ }^{90}$ De Rotterdamse Standaard voor projectmatig werken. Handleiding RSPW, “Werken aan fysieke projecten op z’n Rotterdams”, Gemeente Rotterdam, 2008.

91 Dakpark Rotterdam, see <http://www.dakparkrotterdam.nl/>.

92 Staff Report: Climate Change Adaptation Strategy, City of Toronto.
} 
Toronto Green Standard (TGS). ${ }^{93}$ The TGS guarantees that heat moderation and stormwaterreduction considerations are taken into account in new developments and re-developments. The TGS is being implemented and secured through the site-plan approval process for new buildings. Green adaptation measures, such as green roofs, green parking lots, and tree planting are integrated into the TGS.

In terms of organization, the responsibility for urban planning lies with the City Planning division, while coordination of adaptation planning is the responsibility of the Toronto Environment Office (TEO). Next to the TEO, the Environmental Policy Group of City Planning also plays a crucial role in coordinating adaptation across divisions. Much input from other city divisions, for instance, went into the creation of the TGS. Hence, the separation of responsibilities entails a rather straightforward approach along divisional lines. Responsibility for green planning is fragmented between the City and TRCA. Horizontal coordination among divisions is a real challenge in an enormous organization of 40,000 civil servants. Compartmentalization was mentioned regularly as a barrier during the interviews. With a dominant central role for the provinces in Canada, and their rather centralized governance system, it can be expected that vertical coordination between the Ontario government and the Toronto municipality is troublesome- the more so because of clashes between political cultures. Geographical coordination across the Greater Toronto Area, other than through the TRCA, does not exist, as there is no regional government.

In terms of management tools to enhance coordination and integration, the TEO installed an Adaptation Steering Group and Working Group consisting of staff of various city divisions and an external consultant to create the Adaptation Strategy. As their successor, the Environmental Risk Management Committee was established in 2009 with the purpose of giving city divisions support to assess their climate change risks. Furthermore, the adaptation strategy explicitly states that one of its goals is to build on existing partnerships to provide protection from climate change. ${ }^{94}$

\section{Conclusion}

The mainstreaming of adaptation into urban planning appears to be focused on water-related issues, as urban flooding is a significant risk in all three cities. Horizontal, vertical, and geographical coordination across policy divisions, government tiers, and jurisdictions is fairly limited and in effect hampers the integration of adaptation. The managerial capacity is rather constrained by the two key barriers of compartmentalization and institutional fragmentation, as perceived by most respondents in each city. These cities show that management tools and strategies are used to help combat compartmentalization and fragmentation, such as multi-stakeholder and multidivisional steering groups and project teams, as well as the creation of an adaptation partnership with non-state actors (London) and the creation of a separate adaptation team (Rotterdam).

\footnotetext{
${ }^{93}$ The Toronto Green Standard is a set of performance measures related to sustainable site and building design for new developments. See $<$ http://www.toronto.ca/planning/environment/index.htm $>$.

${ }^{94}$ Adaptation strategy, supra note 59.
} 
Respondents do see opportunities in mainstreaming adaptation into assessment tools, standards, and procedures of related policy divisions. The most prevalent integration mechanisms are Sustainable Design and Construction Standards, of which the Toronto Green Standard is a prime example. Furthermore, multifunctional forms of land use are a stimulus for interdisciplinary cooperation - to the extent of being seen as the solution to merging the compact city and the green city.

\section{Political Capacity}

\section{A. London}

With respect to accountability, in the UK consultation in planning processes is a formal procedure regulated by law. ${ }^{95}$ There is a national portal through which information on planning processes and all planning documents of local authorities can be retrieved. ${ }^{96}$ The GLA's strategy documents undergo a two-stage consultation process (one for GLA stakeholders and one for the public at large), based on published drafts. There is no formal procedure for stakeholder involvement during the creation phase. At the borough level, planning documents also undergo public examination. Reports of planning-application processes are made public on the boroughs' websites. There is also a London Development Database, monitoring the planning permissions of all boroughs through to completion. For most people it is a complex, technical process. In practice, the control over policy-planning processes is predominantly political-councillors provide the checks and balances. Civil society is able to put pressure on the system in a bottom-up manner by influencing the councillors.

The political support for climate policy in London is very high, albeit primarily for mitigation policy. As one respondent said, "adaptation is still the poor cousin". ${ }^{97}$ There has been a considerable push from the insurance industry, which ends up paying for flood damage. Nevertheless, the party-political tensions between the GLA and the boroughs, as well as the short-termism of politics, are seen by respondents as dangers to the continuation of adaptation planning. Thus many respondents mentioned the establishment of strong links between adaptation and mitigation as a good opportunity to move adaptation forward; for instance, by promoting green roofs as both an insulator and heat moderator. Furthermore, the political profile of adaptation is enhanced by the frequent publications of the London Climate Change Partnership. The GLA used the momentum of the publication of the new UKCP09 climate projections to raise political awareness and support for adaptation.

The reason why London is so advanced in climate policy is largely due to the leadership of previous Mayor Ken Livingstone. Using his powers over planning, he pushed climate change into London's development agenda. He has put so many climate requirements in GLA policies

\footnotetext{
95 Barry Cullingworth and Vincent Nadin, Town and Country Planning In The UK (Routledge, 14th ed., 2006).

${ }^{96}$ Planning Portal, Department for Communities and Local Government, <http://www.planningportal.gov.uk/ england/public/>.

${ }^{97}$ Policy Officer, London Councils. Interviewed September, 2009.
} 
that it has created a culture shift and has set the standard. The new Mayor has continued this approach, and the expectation is that there will be an even greater push for green infrastructure as an adaptation measure. The Environment Agency has also played a key role in pushing the adaptation agenda. Bottom-up leadership was provided by dedicated officers from the GLA's environment team.

\section{B. Rotterdam}

With respect to accountability, involvement of stakeholders and the public in planning processes is regulated by the Dutch Spatial Planning Act. However, how decisions are ultimately made and by whom, is less transparent. This is primarily a matter of political rather than public involvement. Nevertheless, NGOs are a considerable force in preventing further loss of green space, as evidenced on many occasions in Rotterdam. Urban planners in Rotterdam have had several successful experiences with public participation in the crafting stage: the master plan for the Dakpark project, for instance, was based on a pro-active consultation of citizens, whose preferences on the park's design were taken into account.

The political buy-in for adaptation is very high in Rotterdam. Urban planning played a role in raising awareness and enthusiasm for adaptation by making "The Flood" a key theme of the International Architecture Biennale of 2005, which resulted in a new vision for the city. ${ }^{98}$ This represented a key turning point: water was framed as a friend instead of an enemy, as an opportunity to transform Rotterdam into an attractive city. Water became the starting point and not the stumbling block for urban design. What helped the uptake of adaptation was the breakdown of this vision into smaller innovative projects, which were readily taken on board by politicians. These projects are perceived to be manageable within the time-horizon of politicians, and are not too costly yet still quite visible. Rotterdam Climate Proof has been trying to maintain high political support by continuously stressing the economic spin-off of the adaptation programme: how the water-expertise Rotterdam is building attracts business and generates jobs.

Former Mayor Opstelten has been an important leader for climate policy in general. He founded the Rotterdam Climate Initiative and committed the city to a fifty per cent reduction in carbon dioxide emissions by 2025. He founded the Rotterdam Climate Office for the implementation of mitigation and adaptation programmes, the first one of its kind in the Netherlands. Alderman Bolsius was the driving force behind an extensive programme to upgrade the quality of the public realm, including urban green space, and thus created favourable conditions for climate-greening Rotterdam. Nevertheless, most political will since 2006 has been driven by the passion and stamina of a few people in water management and the Rotterdam Climate Proof team, providing bottom-up leadership.

${ }^{98}$ Rotterdam Water Stad 2035, Pieter de Greef, ed., 2005. 


\section{Toronto}

With respect to accountability, public participation is guaranteed in Provincial Planning Acts, and the Canadian planning system is considered to be consensual. ${ }^{99}$ Toronto City Planning has a Community Planning section which regularly consults public representatives and other city departments on development projects. Public consultation has been part of the creation of the Toronto Green Standard, as well as approval of the Toronto Official Plan. An extensive consultation process was put in place for the development of the adaptation strategy. Input was obtained from more than a dozen experts. Public opinion was actively sought: six public hearings were held directly after the publication of the adaptation strategy.

The political buy-in to climate policy is high in Toronto, with a predominant focus on mitigation. This stems from Mayor Miller's chairmanship of the C40 Cities Network on Climate Change. The flood of 2005 is generally seen as the key driver for the placement of adaptation on the political agenda. Strong support from the Council has been achieved by focusing on short-term actions and by employing a strategy of incremental change. The adaptation strategy puts much emphasis on short-term activities. The Toronto Green Standard gained momentum through a step-by-step approach. It started as a voluntary standard. Gradually targets were raised, and as of 2010 the standard has become mandatory. Furthermore, adaptation measures are linked with mitigation measures, for instance the doubling of the tree canopy initiative. Moreover, the Toronto Urban Climate Change Network was established in 2008 as an expert network of governmental, NGO, and university representatives, to provide continuous advice and keep adaptation on the political radar.

In the absence of leadership from the federal and provincial levels, the City of Toronto has taken on a remarkable degree of leadership, as demonstrated by the adaptation strategy, the Wet Weather Flow Master Plan, the Toronto Green Standard, and the Green Roof by-law. The Mayor has been quite persistent in pushing the climate agenda. Bottom-up leadership has been driven by a few committed executive champions from several city divisions, supported by external experts. The TRCA has played an important role in promoting adaptation in the Greater Toronto Area, stemming from its knowledge and mandate on the governance of watersheds. As external expert, the Clean Air Partnership has been crucial in the development of Toronto's adaptation strategy.

\section{Conclusion}

The political capacity is high for all three cities, perhaps explaining their front-runner status. Accountability is generated through political checks and balances. The public is able to have its voice heard by pressuring the politicians. The political will for, and leadership in, climate policy is high in each city. Although the short-termism of politicians and their inclination towards mitigation are regarded as barriers by respondents, these cities employ several strategies to maintain political support.

\footnotetext{
${ }^{99}$ Wolfe, supra note 52.
} 


\section{Resource Capacity}

\section{A. London}

Economic resources for climate-greening are very limited as a result of other public priorities from national to local governance levels. Green space is very poorly resourced in England, which has fostered a culture of widespread decline. ${ }^{100}$ There is little funding for adaptation from the national government when compared to funding for mitigation. The Mayor has allocated a portion of his budget for the urban-greening programme related to climate change. The boroughs own most public land, but the maintenance of green space is expensive, and land in London is simply too expensive to enable the public acquisition of new green space.

The GLA suffers from insufficient human resources to climate-green London. The GLA's Development and Environment Group recently faced serious cutbacks: as of the end of 2009, there is only one dedicated adaptation officer. Local authorities lack human resources with knowledge of adaptation planning, and they lack management skills to break down professional silos so as to achieve an integrated approach to climate-greening. ${ }^{101}$ More training is needed, for example through urban-design courses.

The knowledge-base for adaptation is gradually growing, although it is mainly geared towards technical knowledge. The central government allocates significant funds for climate research, such as the UK Climate Impacts Programme, resulting in regional climate projections and tools for informing local policy. ${ }^{102}$ The London Climate Change Partnership regularly conducts research to raise technical knowledge on adaptation measures. In close cooperation with Living Roofs, the GLA has issued a technical report on green roofs. ${ }^{103}$ A records centre for open space and biodiversity was established in $2006 .{ }^{104}$ Knowledge on building activities can be found in the London Development Database.

\section{B. Rotterdam}

In terms of economic resources, no dedicated adaptation funds are provided to Rotterdam by higher government levels other than research funds from the national Knowledge for Climate programme. Rotterdam Climate Proof $(\mathrm{RCP})$ is funded entirely by the municipality. The programme has been established for four years (2008-2012) with a budget of thirty-one million euros. Other municipal budgets are also used for adaptation programmes through integration into the publicrealm programmes. Large parcels of land in the city are owned by the municipality. Rotterdam has considerable funds and land available for climate-greening.

\footnotetext{
100 Is the grass greener ...? Learning from international innovations in urban green space management, Commission for Architecture and the Built Environment (2004).

${ }^{101}$ How we shift funding and skills to green our cities, Commission for Architecture and the Built Environment (2009).

${ }^{102}$ See for instance 'The Local Climate Impacts Profile' (LClips) for boroughs.

${ }^{103}$ Living Roofs and Walls Technical Report: Supporting London Plan Policy. Mayor of London (2008).

${ }^{104}$ Green space information for Greater London, <http://www.gigl.org.uk/>.
} 
In terms of human resources, there are six RCP staff dedicated to adaptation planning. This is quite unusual and symbolizes the political priority that the climate-policy programme enjoys. Furthermore, a growing group of civil servants within the three major divisions for physical planning is also involved in adaptation activities on a part-time basis. The know-how of staff on adaptation is rapidly growing, although it is focused on water-management issues. The management skills to overcome compartmentalisation are still lacking. Staff are hired for, and judged by, their sectoral expertise, and they are not challenged to think laterally. Furthermore, the three physical divisions have quite different organizational cultures, which tend to clash. It is not the quantity but the quality of human resources that seems to be an issue for adaptation planning.

Most respondents acknowledged that knowledge on adaptation planning needs to be further developed, and this is addressed in various initiatives with heavy involvement from external experts. Knowledge generation is one of the RCP's pillars, with the ultimate goal of making Rotterdam a knowledge centre for innovative water management and urban delta technology. Much of the technical and social-scientific knowledge is gradually built up through Rotterdam applied Knowledge for Climate research programme. ${ }^{105}$ In addition, Rotterdam is setting up a Climate Campus consisting of a high-tech science, business, and NGO community. The new national water research centre will also be located in Rotterdam.

\section{Toronto}

Economic resources for climate-greening Toronto are rather constrained. The funding of public services is a fundamental issue, ${ }^{106}$ and is further aggravated by the recent economic crisis. Most spending on climate policy is dedicated to mitigation, as was confirmed in the interviews. Nevertheless, a considerable amount is reserved for dealing with measures to prevent (basement) flooding in four priority areas, and some money is available for tree planting and subsidies for green roofs. Although some land is in the hands of the city and the TRCA, most is under private ownership. Fortunately the TRCA owns a large amount of land crucial to the conservation of watersheds, as well as hazard lands for flood alleviation.

Very few human resources are available for adaptation compared to mitigation. There is one dedicated adaptation officer, who is not resourced to effectively manage, coordinate, and liaise with people in the entire civil service. Several other relevant divisions have officers working part time on adaptation. The know-how and skills level pose yet another limitation. Most staff lack knowledge on how adaptation planning could be integrated into their planning processes and routines. Several training programmes have been set up by City Planning and the TRCA to resolve this. A few respondents mentioned the organizational culture as a stumbling block: people are resistant to change, particularly when they are surrounded by uncertainty, as is the case in adaptation issues.

\footnotetext{
${ }^{105}$ Rotterdam is one of the so-called hotspots of Knowledge for Climate. See www.knowledgeforclimate.org.

${ }^{106}$ Hanna and Walton Roberts, Quality of Place and the Rescaling of Urban Governance: The Case of Toronto, 33(3) Journal of Canadian Studies (2004).
} 
Knowledge resources are gradually being built up. The creation of the Toronto Urban Climate Change Network is an attempt to gain and disseminate knowledge. The external Clean Air Partnership is quite knowledgeable on adaptation, and has published several reports. The TRCA is recognized for its knowledge regarding flood-plain management. It also has developed expertise in green measures for stormwater retention and flood alleviation. A recent UFORE study ${ }^{107}$ gave a detailed inventory of forests in Toronto, including their ecosystem services. The city has a ten-year-old database that registers every tree in Toronto.

\section{Conclusion}

The resource capacity of the cities needs considerable development. Lack of funds and land were often mentioned as key barriers to climate-greening, even in Rotterdam, although it is clear from the comparison that this city is well off in comparison with London and Toronto. Rotterdam is also relatively better off in terms of human resources, with a dedicated team for adaptation planning. The lack of know-how and skills among the staff presents a barrier, while education programs represent a key opportunity to improving this deficit. Cultural barriers pose challenges to the integration of adaptation in each city. It has also been proven difficult to transform generalized knowledge and policies into concrete and feasible measures on the ground. While there is a growing body of knowledge on regionalized climate impacts and technical adaptation measures, social-scientific research programs on policy evaluations and governance issues are mostly absent. Networks, such the London Climate Change Partnership, Toronto Urban Climate Change Network, and Rotterdam Climate Campus are particularly helpful in enhancing knowledge resources.

\section{Learning Capacity}

\section{A. London}

Uncertainty on local impacts and financial implications of adaptation policies was expressed as an important barrier by many respondents. Dealing with uncertainty is a real challenge, since policies that are put out for public consultation must have a strong evidence base to support them. Besides conducting impact and financial assessments to provide the technical and economic rationale of measures, the GLA also pragmatically explores overseas examples of proven technical adaptation solutions. Additionally, new approaches have been explored. The Tyndall Centre for Climate Research has developed simulation modules, based on scenariobuilding for climate-driven socio-economic and land-use changes, as well as options for the GLA's policy responses. ${ }^{108}$ Furthermore, real-life experiments are being conducted with research institutes. An example is the Lucid research project, which aims to explore the effects of changes in green cover on the local climate-it promises to refine the understanding of the amount and

\footnotetext{
${ }^{107}$ See <http://www.ufore.org/action/09-00.html>.

$108 \mathrm{Jim}$ W. Hall et al., How can cities grow whilst reducing emissions and vulnerability? Tyndall Centre for Climate Change Research, Newcastle University 2009.
} 
the kind of green space required to reduce the UHI effect. ${ }^{109}$ In the Drain London project, green roofs are monitored to acquire data on their actual water-drainage potential and impact on the UHI effect.

With respect to continuous learning, there are several web-based databases policymakers have at their disposal for the dissemination and continuation of knowledge transfer. ${ }^{110}$ The GLA organizes numerous workshops and training sessions internally and for the boroughs around sustainable design and master-planning for climate change. There are also various external networks that facilitate the exchange of experiences and best practices. Two London-wide networks exist for climate change: the London Climate Change Partnership and the London Environmental Coordinators' Forum. On a regional scale, there is the Three Regions Climate Change Group for the south-east of England. The Mayor of London participates in the C40 Cities Climate Leadership Transnational Network, allowing the exchange of experiences with other cities around the world. Occasionally, the GLA holds stakeholder-dialogue sessions: in October 2009 six sessions were planned around the UKCP09 projections and their impact on those stakeholders.

\section{B. Rotterdam}

Dealing with uncertainty is quite challenging in Rotterdam, as the local impacts of climate change are as yet unknown, as is the effectiveness of adaptation measures. However, Rotterdam appears to embrace these uncertainties. They are turned into opportunities for real-life experimentation-for learning-by-doing. Several visible pilot projects are being set up in Rotterdam. The regeneration of the old un-embanked city harbour is the testing ground for creative new solutions, such as adaptive and floating buildings. In the Dakpark project, multifunctional forms of land use with adaptation measures are being piloted. In 2011, the first water plaza will be created (a public square that can retain water in times of extreme rainfall). Technical solutions are also developed by the RCP such as the Climate Atlas which will list local climate effects, the Climate Route Planner showing potential measures, and the Climate Barometer to monitor progress in adaptation planning.

In terms of continuous learning, many respondents acknowledged that an organizational (workshops, training, etc.) or technical (databases, intranet) infrastructure is currently missing to distribute information across staff of relevant city divisions. As one respondent said, "adaptation is so leading-edge that you need to organize your own knowledge development". ${ }^{111}$ Exchange with stakeholders primarily takes place through external networks. Rotterdam is keen on learning from, and sharing its own expertise with, foreign cities, such as through its membership of the C40 network. Within this network, Rotterdam has taken the initiative to create a separate group of cities, called Connecting Delta Cities. ${ }^{112}$ As discussed in the introduction to this special issue

\footnotetext{
109 The draft climate change adaptation strategy, supra note 43 .

110 See the London section regarding knowledge resources.

111 Policy Officer, Municipal Works Rotterdam, interviewed September 2009.

112 See <http://www.rotterdamclimateinitiative.nl/nl/delta_cities_website/home>.
} 
of Climate Law, in September 2010 the international conference "Delta Regions In Time of Climate Change" was held in Rotterdam, bringing leading researchers and policymakers together to strengthen international cooperation in adaptation planning.

\section{Toronto}

In Toronto it was emphasized that adaptation policy needs to be evidence-based, so that uncertainties are reduced. Uncertainties regarding local climate projections are addressed through a Climate Drivers Study. Other technical approaches are cost-benefit analyses: for instance, a cost-benefit analysis was made for green roofs to support their incentive programme, and for the Toronto Green Standard to support its mandatory character. A primary means to manage uncertainty in Toronto is through the environmental risk assessment approach, which is currently developed with climate change as the focal point. Other approaches, such as real-life experimentation, are undertaken, albeit in a modest way. One such experiment is the so-called Sustainable Sidewalk. This pilot project is meant to help trees on sidewalks flourish. Toronto has also experimented with mandatory downspout disconnection programmes to reduce stormwater run-off. Several studies conducted in association with universities have been directed at monitoring the performance of green roofs for stormwater management.

For the fostering of continuous learning, Toronto draws mostly on external networks. Internally, an adaptation reference collection with over 300 documents was compiled for city staff. ${ }^{113}$ Webinars, presentations, and training sessions were also used to disseminate adaptation information to city staff. Moreover, an external consultant, Clean Air Partnership, runs webinars which are accessible to staff, and has initiated a network among Canadian municipalities, called Alliance for Resilient Cities, as a community of practice for sharing information on adaptation planning. The Toronto Urban Climate Change Network consists of external experts. For acquiring information from international peers, Toronto uses two networks: the C40 Cities network and the US-based Urban Leaders Adaptation Initiative.

\section{Conclusion}

Dealing with the uncertainties around climate impacts and the effects of adaptation measures at the local scale is a challenging task in adaptation planning. Uncertainty was perceived to be a serious barrier to the governance capacity in all three cities. Nevertheless, there is one remarkable difference: in Rotterdam uncertainty is regarded as an opportunity for testing new and innovative adaptation measures, while in London and Toronto uncertainty is primarily treated as a risk that must be contained. The facilitation of continuous learning processes is another critical aspect that could be enhanced in the three cities. External learning networks are generally in place, and all three cities belong to the C40 network. With the exception of London, the infrastructure to support internal networks is less developed or less accessible, resulting in a poor outreach. This frustrates the objective of ongoing knowledge-dissemination among staff.

${ }^{113} \mathrm{See}<\mathrm{http}: / /$ www.toronto.ca/teo/climate_change_adaptation/index.htm>. 


\section{ConCLuSIONS}

Despite differences in urban governance arrangements, the common findings from London, Rotterdam, and Toronto reveal legal and political capacity to be the strongest sub-capacities. Legal capacity is strong because of the ample regulatory regimes for the protection and enhancement of green space. This reduces the risk that these cities will become even more "impermeable", and therefore more vulnerable to excessive rainfall and heat stress. Political capacity is strong due to a combination of strong political will and leadership. Managerial capacity is rather mediocre due to the presence of compartmentalization and fragmentation, which represent the two key barriers to governance capacity. Institutional fragmentation is also mentioned by Penney and Wieditz as a key constraint, based on six metropolitan regions in developed countries, ${ }^{114}$ and in Lindley and associates, based on a case study of the Greater Manchester conurbation. ${ }^{115}$ This factor is blocking the effective interaction of different governance levels, actors, and sectors needed for the purpose of mainstreaming adaptation. Resource capacity is also rather weak in the three cities. The main barriers to this capacity are the lack of economic resources, as well as the deficit in know-how of urban planners and in social-scientific knowledge, which in turn makes it difficult to translate general policy recommendations into concrete adaptation measures. This is in line with the findings in the literature that the integration of adaptation in urban planning is limited to the general level of policy formulation. ${ }^{116}$ Learning capacity is also still rather weak: the uncertain character of climate change is perceived to be a key barrier in these cities, as was evidenced in the literature. ${ }^{117}$

The three weaker capacities show ample opportunity for growth. Critical to the strengthening of the managerial capacity is the mainstreaming of adaptation. As the literature on adaptation already suggests, ${ }^{118}$ we have found that the mainstreaming of adaptation is critical in the local urban environment too. The more green-adaptation measures can be integrated into related policy areas and linked up with existing social, economic, and environmental measures, the more successful the climate-greening of cities is likely to be. Mainstreaming can be effectuated by the integration of adaptation concerns into existing urban-planning processes, codes for sustainable building, environmental impact assessments, and risk-assessment processes. It should be realized that this mainstreaming can vary from one green-adaptation measure to the next: green roofs require a different kind of integration (for instance through codes for sustainable building) than the development of parks (which would happen through more general planning processes for urban renewal and through urban green planning). Another way in which managerial capacity can be strengthened is by establishing explicit links with measures from other policy fields. This

\footnotetext{
114 Jennifer Penney and Ireen Wieditz, Cities Preparing for Climate Change A Study of Six Urban Regions (Clean Air Partnership, 2007).

${ }^{115}$ Lindley et al., supra note 3.

${ }^{116}$ Mickwitz et al., supra note 10 .

117 See authors mentioned, supra note 28 .

${ }^{118}$ See authors mentioned, supra note 18 .
} 
is in line with a literature review of eighty-seven peer-reviewed articles, ${ }^{119}$ which concludes that climate change is rarely the primary motivator for adaptation action, thus reinforcing the importance of mainstreaming and no-regrets measures. Our research has revealed some concrete linkage measures: multifunctional forms of land use, such as green roofs, are able to interlink different societal governance themes. Resource capacity can be enhanced by continuously investing in training programmes for staff and other stakeholders in adaptation planning, and by building social-scientific knowledge-for instance, researching the effectiveness of policy interventions and different governance arrangements for adaptation planning. The capacity for learning can grow by providing and maintaining infrastructure for learning processes; by maximizing the use of all available stakeholder networks; and by using stakeholder-dialogue to enhance the learning process. The case of Rotterdam shows that uncertainty can be turned into an opportunity through pilot projects and innovative experiments, thus enhancing learning capacity and creating a new knowledge-based economy in adaptation expertise.

A general finding is that, while being able to mainstream adaptation into new developments due to urban-renewal programs, the capacity of urban planning to adapt the existing built environment (which is about eighty per cent of the urban environment) is very limited. In order to raise its influence on adaptation planning, more attention should be paid to developing capacity for retrofitting the existing building stock. Further research is recommended on what kinds of capacities would be needed to effectively govern this, and how private actors (as the main owners of buildings) could be involved in the process.

Finally, our research suggests that the governance of adaptation is still predominantly a government affair in London, Rotterdam, and Toronto. This is because protection against urban flooding and prevention of health problems arising from heat stress are perceived to be public goods, and consequently are the responsibility of the public sector. ${ }^{120}$ Involvement of nonstate actors in these cities is currently mostly limited to partnerships in the policy-preparation phase. Active involvement of the private sector in the planning and implementation of adaptation measures could raise governance capacity. It has the potential to increase resource capacity in terms of economic resources: private actors are key investors, as well as owners of land and buildings in cities. They could also enhance learning capacity, for instance by actively participating in networks in which best practices are shared, and by taking part (financially) in innovative adaptation projects. It is our recommendation that more research is undertaken to identify the scope of governance arrangements for adaptation in which public and private actors share responsibilities.

${ }^{119}$ Lea Berrang-Ford, James D. Ford, and Jaclyn Paterson, Are we adapting to climate change?, 21(1) Global Environmental Change 25 (2011).

${ }^{120}$ Stine Aakre and Dirk T. G. Rübbelke, Objectives of public economic policy and the adaptation to climate change, 53(6) Journal of Environmental Planning and Management 767 (2010). 